\title{
THE EPIDEMIOLOGY OF ANABOLIC-ANDROGENIC STEROIDS USE AMONG SECONDARY STUDENTS (VALENCIA-SPAIN)
}

\section{EPIDEMIOLOGÍA DEL CONSUMO DE ESTEROIDES ANABOLIZANTES ENTRE ESTUDIANTES DE SECUNDARIA (VALÈNCIA-ESPAÑA)}

\author{
Víctor Agulló Calatayud ${ }^{1,2}$, Teresa Samper Gras ${ }^{1}$, Julia Aguilar Serrano ${ }^{3}$ y Sofía Tomás Dols ${ }^{4}$ \\ 1 Departament de Sociologia i Antropologia Social. Universitat de València. España \\ 2 UISYS. Unidad Mixta de Investigación. Universitat de València-CSIC. España \\ ${ }^{3}$ Freelance. Especialista en Prevención de Drogodependencias y otras Conductas Adictivas
}

${ }^{4}$ Médica especialista en Salud Pública. Ex directora General de Drogodependencias. Conselleria de Sanidad Universal y Salud Pública, G. V., España

\section{Abstract}

The consumption of anabolic-androgenic steroids (AAS) is continuously growing in recent years among young people. The purpose of the current study was to examine the proportion of students who reported AAS use, explore other drug use among them and finally to determine the sociodemographic profile of the AAS consumption amongst a sample of students in the Valencian Region (Spain). Method. Data was taken from a self-administrated survey of a representative sample of 1,1162 Valencian students. A total of 252 schools participated in the study. Results. The findings show that $3.3 \%$ of surveyed students reported that they had consumed AAS. Males reported to take anabolic more frequently than females. The older they are the more frequent the reporting of consumptions. Among users of AAS it exists a higher prevalence of consumption of cannabis $64.2 \%$, cocaine $23.8 \%$, hypnotics $22.9 \%$, ecstasy $16.8 \%$, LSD $14 \%$ or heroine $4.1 \%$, compare to nonusers. Conclusion. The study shows that the consumption of steroids is mainly masculine, a clear association with polyconsumption, frequent scheming as the main source of getting them and that the consumption of these substances is bigger among students whose family situation is characterized by the absence of a masculine figure (single mother or widow) in comparison with those whose parents are married.

Keywords: Anabolic steroids, Drug use, Drug use in Europe, Adolescents, Epidemiology.

\section{Resumen}

El consumo de esteroides anabolizantes androgénicos (AAS) está creciendo continuamente en los últimos años entre los jóvenes. El propósito del presente estudio fue examinar la proporción de estudiantes que reportaron uso de AAS, explorar el uso de otras drogas entre ellos y, finalmente, determinar el perfil sociodemográfico del consumo de AAS entre una muestra de estudiantes de la Comunidad Valenciana (España). Método. Se tomaron datos de una encuesta autoadministrada de una muestra representativa de 1,1162 estudiantes valencianos. Un total de 252 escuelas participaron en el estudio. Resultados. El 3.3\% de los estudiantes encuestados informaron que habían consumido AAS. Los hombres informaron tomar anabólicos con más frecuencia que las mujeres. A mayor edad, mayor consumo de esteroides. Entre los usuarios de AAS existe una mayor prevalencia de consumo de cannabis $64.2 \%$, cocaína 23.8\%, hipnóticos $22.9 \%$, éxtasis $16.8 \%$, LSD $14 \%$ o heroína $4.1 \%$, en comparación con los no usuarios. Conclusión. El estudio muestra que el consumo de esteroides es principalmente masculino, una clara asociación con el policonsumo, los frecuentes trapicheos como principal fuente de obtención de la sustancia y que el consumo de estas sustancias es mayor entre aquellos estudiantes cuya situación familiar se caracteriza por la ausencia de una figura masculina (madre soltera o viuda) en comparación con aquellos cuyos padres están casados.

Palabras clave: Esteroides anabolizantes, Consumo de drogas, Consumo de Drogas en Europa, Adolescentes, Epidemiología.

Correspondence: Víctor Agulló Calatayud | victor.agullo@uv.es 
The consumption of anabolic-androgenic steroids (AAS) has been growing continuously in recent years since becoming an important worldwide health problem. Initially they were circumscribed to the field of elite sports, where they are used to increase muscle mass and strength (Kanayama \& Pope, 2018; Skårberg, Nyberg, \& Engström, 2009; Todd, 1987). The consumption motivations diversify with other consumer populations and contexts (Agulló, González, Valderrama, \& Aleixandre, 2008; Sjöqvist, Garle, \& Rane, 2008). Epidemiological reports have shown that although the prevalence of AAS use among the general population is low, other subpopulations such as sportspeople (18.4\%) and athletes (13.4\%) display high prevalence rates (Sagoe \& Pallesen, 2018). Several studies have founded a higher prevalence of AAS in young people and males compared to general population (Horwitz, Andersen, \& Dalhoff, 2019; Petrocelli, Obserweis, \& Petrocelli, 2008; Thorlindsson \& Halldorsson, 2010). Many young people use them for athletics purposes (Breivík, Hanstad, \& Loland, 2009; Mulcahey, Schiller, \& Hulstyn, 2010) and even for recreational sport (Bahrke, Yesalis, Kopstein, \& Stephens, 2000; Kartakoulis, Phellas, Poulokas, Petrou, \& Loizou, 2008; Vorona \& Nieschlag, 2018), whereas others use these drugs for cosmetic purposes rather than to enhance sports performance (Hakansson, Mickelsson, Wallin, \& Berglund, 2012; Hildebrandt, Lai, Langenbucher, Schneider, Yehuda, \& Pfaff, 2011) or even for occupational motives (Agulló, Castelló, \& Valderrama, 2014; Avilez, Zevallos, \& Taype, 2017; Costa, et al., 2010) or, in a less extend, to conceal concomitant drug use, to alleviate insecurity or low self-esteem, to become brave, or in preparation of committing a crime (Petersson, Bengtsson, Voltaire, \& Thiblin, 2010). The body ideal increasingly featured in the media, characterized by large muscles, well defined abdominals, and extremely low body fat, becomes a main goal to achieve (Labre, 2002) determining a muscularity pattern to imitate. Young people who use AAS face greater health risks compared to other age groups, such as acne, gynaecomastia, reduced libido, erectile dysfunction, liver toxicity, increased mood swings, aggression, physical closure, interpersonal problems and antisocial behaviours which may cause particularly serious physiological, psychological, and social problems for people in this age group (Griffiths, Brendan, Degenhardt, Murray, \& Larance, 2018; Hauger et al., 2019; Petersson, Bengtsson, Voltaire-Carlsson \& Thiblin, 2010; Smit \& de Ronde, 2018;
Van Amsterdam, Opperhuizen, \& Hartgens, 2010). Alike AAS abuse is associated with increased morbidity and mortality (Horwitz et al., 2019). Despite the high prevalence of AAS use, this epidemic has remained hidden and not received the attention that it deserves because it has escaped the attention of public health authorities (Goldman, Pope, \& Bhasin, 2019). Thus, there is an increasing interest to know more about AAS patterns of use amongst young people and school population, a particularly vulnerable age group. The present study aims to examine the proportion of students who reported lifetime AAS use, explore other drug use among those who reported AAS consumption and finally to determine the sociodemographic profile of the AAS user amongst a representative sample of students in the Valencian Region (Spain).

\section{METHOD}

\section{Sample}

The number of survey respondents was 1,1162 . In this group, $47.6 \%$ were male and $52.4 \%$ were female, with a median age of 16.26 years $(D T=1.33)$. By ages, 1,245 (11.1\%) were 14 years old; $2,374(21.3 \%)$ were $15 ; 2,477$ (22.2\%) were 16; 2,370 (21.2\%) were 17; and 2,696 (24.2\%) were 18 years old. Nine people declined to participate in this study. The sampling error of the sample set, with a confidence level of $95.5 \%$, was $\pm 0.41 \%$, with $P=Q$.

\section{Instruments}

The questionnaire collected information in 10 areas: sociodemographic data (age, sex, nationality, family situation, etc.), evolution of academic studies (subjective perception, repeated grades, absenteeism), prevention activities in and out the classroom, information on drugs (sources and information needs on drugs), perceived consequences of drug use, perception of risk with regard to the use of different drugs, drug use by respondents (varying according to substances, age of initial use, frequency and place of use), leisure activities, history of parental drug use and permissiveness of drug use in family environment. For the present study, we only analyze data concerning AAS use. Unfortunately, as a limitation of the study we have no data concerning what type, dosage or duration of AAS use. 
The questionnaire was presented in both official languages of the Valencian Region: Spanish and Valencian. The bilingual nature of the questionnaire allowed pupils to answer questions in their home language. The average time to complete the questionnaire was 30 minutes. Survey takers, who had had previous training, were in charge of handing out the questionnaires in the classroom, explaining their purpose and guaranteeing anonymity and data confidentiality.

\section{Procedure}

The study was carried out between in 252 schools. Ethics approval was obtained. The sample consisted of multistage clusters that was carried out with proportional allocation. The selection of the sample was made after dividing the target population by Unit of Community Prevention UPC (local government groups aiming to prevent drug abuse within the community) existing in the Valencian Region in Spain and which were accredited by the main Drug Abuse Directorate of the regional Health Council. In each cluster of UPCs $(n=58)$ the sample was analysed with a margin of error of $6 \%$ and a confidence level of $95 \%$. Afterwards, primary units of the sample were selected (educational centres, as defined by their legal ownership) as well as secondary units (classrooms according to course levels). The selection of the educational centres was carried out using the list of the existing centres in each municipality of the Valencian Region provided by the regional Education Council. These schools were grouped according to the geographical area of the UPC's activity. Among those surveyed, 9.31\% lived in the province of Castelló, $57.75 \%$ in the province of València, and $32.94 \%$ in the province of Alacant.

With respect to the academic courses to which the groups belonged, $25.4 \%$ were in the third year of compulsory secondary studies (ESO in Spanish), $21.8 \%$ were in the fourth year of ESO, $17.5 \%$ were in the first year of Baccalaureate, $8.2 \%$ were in the second year of Baccalaureate, $11.8 \%$ were attending Intermediate Vocational School (CFGM in Spanish), 13.9\% were attending Advanced Vocational School (CFGS), and 1.3\% were participating in the Programme of Social Guarantee (PGS), an alternative vocational programme created for those students who have had severe problems (educational, behavioural, etc) within the traditional system.
Students were also informed of the voluntary nature of their participation in the study which was supported by: Fundació per a l'Estudi, Prevenció i Assistència de les Drogodependències (FEPAD). Generalitat Valenciana. (Spain).

\section{Data Analysis}

The statistical analysis was performed using SPSS version 22.0 and $\mathrm{R}$, free version of S-Plus. This included the chi-square test, and t-test when appropriate. In order to evaluate the relation between the independent variables, stated above, and the consumption of anabolic steroids, a logistic regression analysis was carried out (McCullagh, 1989). To select the variables that fit better the response, a step process was performed based in the Akaike Information Criterion (AIC) -a measure of the goodness of fit of an estimated statistical model-. This process selects a variable if the model explains better the response variable (the AIC value diminishes), although, maybe this variable is not statistically significant $(p<.05)$. A statistic analysis is carried out from the technique of the multiple logistical regression. For that matter, the following information is selected: first, language (Spanish, Valencian or bilingual - Valencian Region has two official languages), school year (Compulsory Secondary Education, High school, Formative Courses), age, gender, marital status of the parents (single mother or father, separated, divorced, unmarried couple, married, widow), who they live with, how are the relationships within the family, if they have been awarded with a scholarship, the quantity of money they get per week (0€, 1-10€, 11-20€, 21-30€, more than $30 €)$, schemes to obtain the money, the notion they have about their studies, if they have repeated a school year, age at which they fail more than 4 subjects, if they have failed to attend classes during the last six months, and, finally, if they have received information about drug addiction in class or out of the classroom.

\section{RESULTS}

The 3.3\% of surveyed students reported that they had consumed anabolic steroids. Males reported to take anabolic more frequently than females $(86.2 \%$ of males, $13.8 \%$ of females; $p<.001)$. The older they are the more frequent the reporting of consumption -increasing from $2.5 \%$ in those aged 14 , to $4.3 \%$ in those aged $18-\left(X^{2}=\right.$ 
10.935, $p<.001)$. It can also be stated that secondary school pupils report a consumption of $3.1 \%$ while medium degree or technical education students report $4.6 \%\left(X^{2}=13.82, p<.001\right)$. Among users of AAS it exists a higher prevalence of consumption of cannabis $64.2 \%\left(X^{2}\right.$ $=49.71, p<.001)$, cocaine $23.8 \%\left(X^{2}=66.27, p<.001\right)$, hypnotics $22.9 \%\left(X^{2}=11.79, p<.001\right)$, ecstasy $16.8 \%$ $\left(X^{2}=75.24, p<.001\right)$, LSD 14\% $\left(X^{2}=79.55, p<.001\right)$ or heroine $4.1 \%\left(X^{2}=57.57, p<.001\right)$, compare to nonusers. Nevertheless, the prevalence is lower in tobacco and alcohol consumption which shows a clear relation between anabolic steroids and polyconsumption.

\section{Logistic regression}

In the first place, it is worth pointing out that the fact of being a woman is a factor that protects significantly from the consumption of AAS, reducing in $75 \%$ the risk of consumption $\left(e^{-1.395}=.25\right)$. This pattern also makes clear the fact that getting the steroids using schemes is the most extended way of obtaining them, given that it raises the risk significantly in $326 \%\left(e^{1.183}=3.26\right)$. In this model (Table 1) there are other variables that, without establishing statistically significant associations, they do record some consumption patterns. In this sense, the variable related to the language shows that Valencian speakers and bilingual individuals they do consume less steroids than Spanish speakers. In the same way, this pattern confirms that students of Compulsory Secondary Education and High school consume less than those students of Formative Courses and that the older they are the bigger the probability of consumption. On the other side, the absence of good relations at home can raise the risk of consumption. Finally, the fact of not repeating a school year, attending classes regularly and getting good marks are aspects that diminish the risk of consumption. Besides, the fact of not getting information about AAS in class increases the risk of consumption, at the same time that it is noticed that getting information outside the school raises the probability of consumption. Lastly, it is worth pointing out that the notion they have about their studies does not record any link with consumption. Consecutively, a selection of the best pattern which explains the consumption is carried out by the process step by step based on the AIC, getting as main variables gender, parents' marital status, and money on hand and sources of obtaining the money: scheming. From this last pattern, different variations are carried out giving priority to the presence of sociodemografic variables.
Table 1. Model of logistic regression for the consumption of anabolic steroids

\begin{tabular}{|c|c|c|}
\hline & Estimate & p-value \\
\hline Constant & -1.32 & .59 \\
\hline Valencian Language (Spanish) & -.27 & .18 \\
\hline Bilingual (Spanish) & .32 & .37 \\
\hline $\begin{array}{l}\text { Compulsory Secondary Education } \\
\text { (Formative Courses) }\end{array}$ & -.19 & .54 \\
\hline Highschool (Formative Courses) & -.18 & .49 \\
\hline Age & .03 & .82 \\
\hline Gender female (Male) & -1.40 & .00 \\
\hline Parents single father/mother (Married) & 1.06 & .18 \\
\hline Unmarried Couple (Married) & .36 & .31 \\
\hline Separated/divorced parents (Married) & .05 & .93 \\
\hline Widow parent (Married) & .57 & .42 \\
\hline $\begin{array}{l}\text { Live with my father and mother (With my } \\
\text { mother) }\end{array}$ & -.04 & .95 \\
\hline Live with my father (With my mother) & -.48 & .56 \\
\hline $\begin{array}{l}\text { Live with my mother and her partner (With } \\
\text { my mother) }\end{array}$ & -.60 & .31 \\
\hline $\begin{array}{l}\text { Live with my father and his partner (With my } \\
\text { mother) }\end{array}$ & -.13 & .91 \\
\hline Live with a relative (With my mother) & .22 & .76 \\
\hline $\begin{array}{l}\text { Live temporary with my mother and father } \\
\text { (With my mother) }\end{array}$ & .84 & .24 \\
\hline Live with others (With my mother) & -12.96 & .98 \\
\hline Normal relations at home (Good) & .29 & .20 \\
\hline Bad relations at home (Good) & .49 & .23 \\
\hline Scholarship No (Yes) & .13 & .57 \\
\hline Money from 1 to $10 €(0 €)$ & .54 & .47 \\
\hline Money from 11 to $20 €(0 €)$ & .20 & .79 \\
\hline Money from 21 to $30 €(0 €)$ & 1.01 & .18 \\
\hline Money more than $30 €(0 €)$ & 1.06 & .16 \\
\hline Schemes Yes (No) & 1.18 & .00 \\
\hline Perception of studies Average (Good) & .00 & .99 \\
\hline Perception of studies Bad (Good) & -.01 & .98 \\
\hline Repeated Course No (Yes) & -.04 & .85 \\
\hline Age fail more that 4 subjects & -.07 & .25 \\
\hline $\begin{array}{l}\text { Not attending Classes last } 6 \text { months No } \\
\text { (Yes) }\end{array}$ & -.20 & .40 \\
\hline Receive Information Drugs in Class No (Yes) & .22 & .40 \\
\hline $\begin{array}{l}\text { Receive Information Drugs outside the Class } \\
\text { No (Yes) }\end{array}$ & -.04 & .81 \\
\hline
\end{tabular}


Again, there is a clear association, already commented, between gender and consumption. Nevertheless, it is worth pointing out that the consumption of steroids is bigger between those students whose nuclear family is that of a single mother/father (increasing the risk of consumption in $188 \%, e^{1.058}$ ) or widow (increasing the risk in $85 \%, e^{0.616}$ ) in comparison with the students whose parents are married. Finally, although not in a significant way, statistically speaking, it is noticed that the fact of having little money $(<20 €)$ diminishes the risk of consumption (Table 2).

Table 2. Model of logistic regression for the consumption of anabolic steroids from the selection of variables which best explain the consumption

\begin{tabular}{lcc}
\hline & Estimate & p-value \\
\hline Constant & -2.79 & .00 \\
Gender Female (Male) & -1.75 & .00 \\
Parents Single Mother/Father (Married) & 1.06 & .03 \\
Unmarried Couple (Married) & .38 & .13 \\
Separated/Divorced Parents (Married) & -.01 & .97 \\
Widow Parent (Married) & .62 & .05 \\
Money from 1 to $10 €(0 €)$ & -.30 & .41 \\
Money from 11 to $20 €(0 €)$ & -.29 & .42 \\
Money from 21 to $30 €(0 €)$ & .37 & .32 \\
Money more than $30 €(0 €)$ & .56 & .13 \\
\hline
\end{tabular}

\section{DISCUSSION}

It has to be stated that the consumption of AAS reported in the study $3.3 \%$ is consistent with international literature in similar studies developed in different geographical contexts: Australia 2.4\% (Dunn \& White, 2011), Brazil 2.7\% (Canuto, Assis, \& Guimarães, 2006), Canada 2.8\% (Melia, Pipe, \& Greenberg, 1996), Jordania 4.2\% (Tahtamouni et al., 2008), Norway -ranges from $0.8 \%$ to 4\%- (Wichstrøm \& Pedersen, 2001; Jensen \& Johannessen, 2015; Sagoe, Mentzoni, Hanss, \& Pallesen, 2015; Sandvik, Bakken, \& Loland, 2018), South Africa 1.4\% (Lambert, Titlestad, \& Schwellnus, 1998) and Sweden 2.9\% (Nilsson, Baigi, Marklund, \& Fridlund, 2001). Alike, a recent epidemiology comparative study on the global prevalence rate of AAS use offers exactly the same global lifetime prevalence 3.3\% obtained in our study (Sagoe,
Molde, Andreassen, Torsheimt, \& Pallesen, 2014). We can also confirm a clear association between the policonsumption of drugs and anabolic steroids and its highest prevalence for boys compare to girls, as have revealed diverse studies (Irigoyen-Coll, 2005; Lundholm, Frisell, Lichtenstein, \& Långström, 2014; Rachon, Pokrywka, \& Suchecka, 2006; Sagoe et al., 2014; Skårberg et al., 2009; Smit \& de Ronde, 2018) according to the stereotype that states the idealized body in contemporary Western societies is a thin and fit physique for the females and a muscular body physique for males (Hausenblas \& Fallon, 2001). Evidence suggests that we need to turn our attention to adolescents and young people to gain a better understanding of AAS use among this particularly vulnerable age group (Agulló et al., 2008; de Ronde, 2019; Thorlindsson \& Halldorsson, 2010).

\section{Conclusions}

The study shows the following aspects: a) the consumption of AAS is mainly masculine, given the fact that being a woman is factor that protects significantly from the consumption; b) The main source of getting anabolic steroids is from frequent scheming; c) There is a clear association between AAS and polyconsumption in a relation that should be studied in depth to design prevention campaigns specially addressed to teenagers; d) The consumption of these substances is bigger between those students whose family situation is characterized by the absence of a masculine figure (single mother or widow) in comparison with those whose parents are married); e) It is noticed that getting information outside the school raises the probability of consumption, which confirms the lack of truthful information about AAS between young people. These conclusions lead us to consider that there is a need for intensifying targeted prevention and harm reduction interventions. On the one hand, we should begin to study this phenomenon in a more contextualized way considering both social, cultural and family-based issues and also analysing the protection that offers the families amongst young people. And, on the other hand, it is concluded that it is necessary that the consumption of AAS becomes part of the health promotion campaigns to be carried out at schools, although always taking into consideration that it is a consumption predominantly masculine. 


\section{REFERENCES}

Agulló, V., González, G., Valderrama, J. C., \& Aleixandre, R. (2008). Consumption of anabolic steroids in sport, physical activity and as a drug of abuse: an analysis of the scientific literature and areas of research. British Journal of Sports Medicine, 42(2), 103-109. doi: $\underline{10.1136 / \mathrm{bjsm} .2007 .036228}$

Agulló, V., Castelló, R., \& Valderrama, J. C. (2014). Beyond elite sports: Analysis of the coverage of anabolic steroids in the Spanish press (2007-2011). Catalan Journal of Communication \& Cultural Studies, 6 (2), 197-220. doi: 10.1386/cjcs.6.2.197_1

Avilez, J. L., Zevallos-Morales, A., \& Taype, Rondán, A. (2017). Use of enhancement drugs amongst athletes and television celebrities and public interest in androgenic anabolic steroids. Exploring two Peruvian cases with Google Trends. Public Health, 146, 29-31. doi: 10.1016/j.puhe.2017.01.011

Bahrke, M. S., Yesalis, C. E., Kopstein, A. N., \& Stephens, J. A. (2000). Risk factors associated with anabolic androgenic steroid use among adolescents. Sports Medicine, 29(6), 397-405.

Breivík, G., Hanstad, D. V., \& Loland, S. (2009). Attitudes towards use of performance-enhancing substances and body modification techniques. A comparison between elite athletes and the general population. Sport in Society, 12(6), 737-754. doi: $\underline{10.1080 / 17430430902944183}$

Canuto, M. H. A., Assis-Ferreira R., \& Guimarães, E. M. (2006). Uso e abuso de drogas ilícitas por jovens do $1^{\circ}$ ano da Universidade Federal de Goiás. Revista Paulista de Pediatria, 24(2), 135-142.

Costa, S. H., da Cunha L. C., Yonamine, M., Pucci, L. L., Oliveira, F. G., de Souza C.G., \& Leles C.R. (2010). Survey on the use of psychotropic drugs by twelve military police units in the municipalities of Goiânia and Aparecida de Goiânia, state of Goiás, Brazil. Revista Brasileira de Psiquiatria, 32(4), 389-395. doi: 10.1590/S1516-44462010005000023

De Ronde, W. (2019). Preventing anabolic steroid abuse: A long way to go. Journal of Internal Medicine, 285(3), 349-350. doi: $\underline{10.1111 / \text { joim.128508 }}$

Dunn, M., \& White, V. (2011). The epidemiology of anabolic-androgenic steroid use among Australian secondary school students. Journal of Science and Medicine in Sport, 14(1), 10-14. doi: 10.1016/j.jsams.2010.05.004

Griffiths, S., Brendan, J., Degenhardt, L., Murray, S., \& Larance, B. (2018). Physical appearance concerns are uniquely associated with the severity of steroid dependence and depression in anabolicandrogenic steroid users. Drug and Alcohol Review, 37(5), 664-670. doi: $10.1111 /$ dar. 12688

Goldman, A. L., Pope, H. G., \& Bhasin, S. (2019). The Health Threat Posed by the Hidden Epidemic of Anabolic Steroid Use and Body Image Disorders Among Young Men. Journal of Clinical Endocrinology \& Metabolism, 104(4), 1069-1074. doi: 10.1210/jc.2018-01706

Hakansson, A., Mickelsson, K., Wallin, C., \& Berglund, M. (2012). Anabolic androgenic steroids in the general population: User characteristics and associations with substance use. European Addiction Research, 18(2), 83-90. doi: 10.1159/000333037
Hauger, L. E., Sagoe, D., Vaskinn, A., Arnevik, E. A., Leknes, S., Jørstad, M. L., \& Bjørnebekk (2019). Anabolic androgenic steroid dependence is associated with impaired emotion recognition. Psychopharmacology. doi:10.1007/s00213-019-05239-7

Hausenblas, H. A., \& Fallon, E. A. (2001). Relationship among Body Image, Exercise Behaviour and Exercice Dependence Symptoms. International Journal of Eating Disorders, 32(2), 179-185. doi: 10.1002/eat.10071

Hildebrandt, T., Lai, J. K., Langenbucher, J. W., Schneider, M., Yehuda, R., \& Pfaff, D. W. (2011). The diagnostic dilemma of pathological appearance and performance enchancing drug use. Drug and Alcohol Dependence, 114(1), 1-11. doi: 10.1016/j.drugalcdep.2010.09.018

Horwitz, H., Andersen, J. T., \& Dalhoff, K. P. (2019) Health consequences of androgenic anabolic steroid use. Journal of Internal Medicine, 285(3), 333-340. doi: 10.1111/joim.12850

Irigoyen-Coll, C. (2005). Esteroides y percepción del riesgo. Health and Addictions/Salud y drogas, 5(1), 119-137. doi:10.21134/haaj.v5i1.124

Jenssen, I. H., \& Johannessen, K. B. (2015). Aggression and body image concerns among anabolic androgenic steroid users, contemplators, and controls in Norway. Body Image, 12, 6-13. doi: 10.1016/j.bodyim.2014.08.009

Kanayama, G., Pope Jr., H. (2018). History and epidemiology of anabolic androgens in athletes and non-athletes. Molecular and Cellular Endocrinology, 15(464), 4-13. doi: 10.1016/j.mce.2017.02.039

Kartakoulis, N. L., Phellas, C., Poulokas, S., Petrou, M., \& Loizou, C. (2008). The Use of Anabolic Steroids and Other Prohibited Substances by Gym Enthusiasts in Cyprus. International Review for the Sociology of Sport, 43(3), 271-287. doi: 10.1177/1012690208098545

Labre, M. P. (2002). Adolescent boys and the muscular male body ideal. The Journal of adolescent health: official publication of the Society for Adolescent Medicine. Journal of Adolescent Health, 30(4), 233-242. doi: 10.1016/S1054-139X(01)00413-X

Lambert, M. I., Titlestad, S. D., \& Schwellnus, M. (1998). Indications of prevalence use in adolescents in two regions of South Africa. South African Medical Journal, 88(7), 876-880.

Lundholm, L., Frisell, T., Lichtenstein, P., \& Långström, N. (2014). Anabolic androgenic steroids and violent offending: confounding by polysubstance abuse among 10365 general population men. Addiction, 110(1), 100-108. doi: 10.1111/add.12715

McCullagh. (1989). Models for discrete multivariate responses. Bulletin of the I.S.I, 53, 407-418

Melia, P., Pipe, A., \& Greenberg, L. (1996). The use of anabolic-androgenic steroids by Canadian students. Clinical Journal of Sport Medicine, 6(1), 9-14.

Mulcahey, M. K., Schiller, J. R., \& Hulstyn M. J. (2010). Anabolic steroid use in adolescents: identification of those at risk and strategies for prevention. The Physician and Sportsmedicine, 38(3), 105-13. doi: 10.3810/psm.2010.10.1815 
Nilsson, S., Baigi A., Marklund, B., \& Fridlund, B. (2001). The prevalence of the use of androgenic anabolic steroids by adolescents in a county of Sweden. European Journal of Public Health, 11(2), 195-197. doi: $\underline{10.1093 / e u r p u b / 11.2 .195}$

Petersson, A., Bengtsson, J., Voltaire-Carlsson, A., \& Thiblin, I. (2010). Substance abusers' motives for using anabolic androgenic steroids. Drug and Alcohol Dependence, 111(1-2), 170-172. doi: 10.1016/j.drugalcdep.2010.04.008

Petrocelli, M., Oberweis, T., \& Petrocelli, J. (2008). Getting huge, getting ripped: A qualitative exploration of recreational steroid use. Journal of Drug Issues, 38(4), 1187-1205. doi: 10.1177/002204260803800412

Rachoń, D., Pokrywka, L., \& Suchecka-Rachoń, D. K. (2006). Prevalence and risk factors of anabolic-androgenic steroids (AAS) abuse among adolescents and young adults in Poland. Soz PraventivMed, 51(6), 392-398.

Sagoe, D., Molde, H., Andreassen, C., Torsheim, T., \& Pallesen, S. (2014). The global epidemiology of anabolic-androgenic steroid use: a meta-analysis and meta-regression analysis. Annals of Epidemiology, 24(5), 383-398. doi: 10.1016/j.annepidem.2014.01.009

Sagoe, D., Mentzoni, R.A., Hanss, D., \& Pallesen, S. (2016). Aggression is associated with increased anabolic androgenic steroid use contemplation among adolescents. Substance Use \& Misuse, 51(11),1462-1469. doi: 10.1080/10826084.2016.1186696

Sagoe, D., \& Pallesen, S. (2018). Androgen abuse epidemiology. Current Opinion in Endocrinology, Diabetes and Obesity, 25 (3), 185-194. doi: 10.1097/MED.0000000000000403

Sandvik, M. R., Bakken, A., \& Loland, S. (2018). Anabolic-androgenic steroid use and correlates in Norwegian adolescents. European Journal of Sport Science, 18(6), 903-910. doi: 10.1080/17461391.2018.1459869

Sjöqvist, F., Garle, M., \& Rane, A. (2008). Use of doping agents, particularly anabolic steroids, in sports and society. Lancet, 371(9627), 18721882. doi: 10.1016/S0140-6736(08)60801-6

Skårberg, K., Nyberg, F., \& Engström, I. (2009). Multisubstance use as a feature of addiction to anabolic-androgenic steroids. European Addiction Research, 15(2), 99-106. doi: 10.1159/000199045

Smit, D.L., \& de Ronde, W. (2018). Outpatient clinic for users of androgenic anabolic steroids: an overview. Netherlands Journal of Medicine, 76(4), 167-175.

Tahtamouni, L. H., Mustafa, N. H., Alfaouri, A. A., Hassan, I. M., Abdalla, M. Y., \& Yasin, S. R. (2008). Prevalence and risk factors for anabolicandrogenic steroid abuse among Jordanian collegiate students and athletes. Eurean Journal Public Health, 18(6), 661-665. doi: 10.1093/eurpub/ckn062

Thorlindsson, T., \& Halldorsson, V. (2010). Sport, and use of anabolic androgenic steroids among Icelandic high school students: a critical test of three perspectives. Substance Abuse Treatment, Prevention and Policy, 5(32), 1-11. doi: 10.1186/1747-597X-5-32

Todd, T. (1987). Anabolic Steroids: the gremlins of sport. Journal of Sport History, 14(1), 87-107.
Van Amsterdam, J., Opperhuizen, A., \& Hartgens, F. (2010). Adverse health effects of anabolic-androgenic steroids. Regulatory Toxicology and Pharmacology, 57(1), 117-23. doi: 10.1016/j.yrtph.2010.02.001

Vorona, E., \& Nieschlag, E. (2018). Adverse effects of doping with anabolic androgenic steroids (AAS) in competitive athletics, recreational sports and bodybuilding. Minerva Endocrinologica. 19 Feb. doi: 10.23736/S0391-1977.18.02810-9

Wichstrøm, L., \& Pedersen, W. (2001). Use of anabolic-androgenic steroids in adolescence: winning, looking good or being bad? Journal of Studies in Alcohol, 62(1), 5-13. 